\title{
Effects of Long-Term (44-years) Tillage Sequences on Wheat Grain Yield in a Dryland Farming System in South Africa
}

Flackson Tshuma ( $D$ 15788709@sun.ac.za)

Stellenbosch University https://orcid.org/0000-0002-2307-1894

Pieter Andreas Swanepoel

Stellenbosch University

Johan Labuschagne

Stellenbosch University

James Bennett

Stellenbosch University

Francis Rayns

Stellenbosch University

\section{Research Article}

Keywords: Long-term tillage, infrequent tillage, tillage sequence, no-tillage, wheat grain yield

Posted Date: July 12th, 2021

DOI: https://doi.org/10.21203/rs.3.rs-682846/v1

License: (c) (i) This work is licensed under a Creative Commons Attribution 4.0 International License. Read Full License 


\section{Abstract}

Aims

To determine the effects of the long-term (44-years) tillage practices on wheat grain yield in a dryland farming system.

Methods

Effects of tillage on soil quality and crop productivity were assessed between 1976 and 2020 in South Africa's Mediterranean climate zone. Seven tillage treatments were investigated: continuous mouldboard (MB) ploughing to a depth of $200 \mathrm{~mm}$, tine-tillage to $150 \mathrm{~mm}$, shallow tine-tillage (ST) to $75 \mathrm{~mm}$, notillage (NT), ST conducted once in two years (ST-NT), ST conducted once in three years (ST-NT-NT), and ST conducted once in four years (ST-NT-NT-NT). Two crop management systems were also investigated: wheat monoculture and crop rotation. We evaluated the long-term wheat grain yield responses from the trial and hypothesised that, with time, the (i) monoculture system will lead to reduced grain yield, (ii) MB sequence will lead to reduced grain yield, (iii) infrequent tillage practices will improve grain yield relative to continuous NT.

Results

The monoculture system led to reduced grain yield over time due to increased weeds. Compared to other tillage treatments in the monoculture system, the MB sequence led to higher $(P<0.05)$ grain yields. However, in the crop rotation system, the NT treatment was the best option as it led to high yield and lower fuel usage. The infrequent tillage sequences failed to significantly improve the grain yield relative to continuous NT.

Conclusions

The infrequent tillage sequences were no better than the NT practice. We recommend that farmers opt for NT and crop rotation to ensure sustainability and avoid intensive tillage.

\section{Introduction}

Historically, most small grain producers in the Mediterranean region of South Africa relied on conventional tillage with mouldboard and disc ploughs to grow crops in monoculture systems (Swanepoel et al. 2016). However, over time, grain yields in these monoculture systems declined due primarily to the build-up of weeds (MacLaren et al. 2021), pests and diseases and declining soil organic carbon (Dube et al. 2020; Swanepoel et al. 2016). Further pressure on these conventional production systems came with the deregulation of the agricultural economy in the 1990s. Farmers had to become self-sufficient as they could no longer get subsidies from the government. This prompted many farmers to change their tillage practices and introduce crop rotation. Relatedly, the departments of agriculture in the Western Cape and KwaZulu Natal Provinces encouraged farmers to adopt conservation 
agriculture (CA) as a means of improving soil quality. Consequently, by the early 2000 s, most farmers had adopted components of CA (Swanepoel et al. 2016).

Conservation agriculture is based on three principles namely, minimum soil disturbance, maintenance of permanent soil cover and crop rotation (FAO 2010). In South Africa, only $14 \%$ of commercial grain farmers have adopted all three principles of CA but at least $40 \%$ have adopted one of the three principles (Findlater et al. 2019). Unlike the rest of South Africa, most small grain producers in the Mediterranean climate region (Western Cape Province) have adopted at least two principles of CA. The minimum disturbance of soil is the most widely adopted component of CA (Findlater et al. 2019) whilst the maintenance of permanent soil cover is the least adopted. The hot dry summers of the Mediterranean climate of the Swartland region in the Western Cape Province are not conducive to soil organic matter sequestration (Swanepoel et al. 2016). The growing of cover crops in the Swartland during the summer in rainfed farms is not possible and producers can only retain the stubble from a previous season to cover soil. The comprehensive adoption of CA can reduce weed pressure (MacLaren et al. 2021), lead to an improvement in soil structure, an increase in soil organic carbon stocks and increased crop yield. Crop rotations may help prevent nutrient loss (Rayns et al. 2010), loosen the soil and break disease and insect pest cycles (Schillinger and Paulitz 2018). In contrast, the adoption of only one or two components of CA may lead to poor control and eventual infestation of weeds and a reduction in yields (Findlater et al. 2019).

Typical CA systems in the Western Cape Province include crop rotations involving wheat (Triticum aestivum), canola (Brassica napus), barley (Hordeum vulgare) and/or legumes such as lucerne (Medicago sativa), lupins (Lupinus spp.) and annual Medicago spp. The Western Cape Province produces about $50 \%$ of South Africa's wheat and $99 \%$ of canola (Liebenberg et al. 2020). Common four-year crop rotation systems in the Swartland region are wheat-canola-wheat-lupin (WCWL) and wheat-medic-wheatmedic (WMWM). Rotation of cereals with a broadleaf crop is important as it enables the use of different selective herbicides to eliminate grass weeds that are difficult to control in systems with cereals only. Wheat, barley and canola are the cash crops, whilst the legumes are used as pasture.

A reduction in tillage can lead to the proliferation of weeds (Udall et al. 2014; MacLaren et al. 2021). Tillage, particularly soil inversion practices with a mouldboard plough is one method farmers can consider to control weeds (MacLaren et al. 2021). However, the continued use of the mouldboard plough may lead to a general decline in soil quality through, amongst other things, the depletion of soil organic carbon stocks, breakdown of soil aggregates and increased soil erosion which may ultimately lead to reduced crop yields. The negative effects of the mouldboard plough have been well documented (Dendooven et al., 2012; Derpsch, 2004; Hobbs et al., 2008; Swanepoel et al., 2015). To minimise soil degradation through tillage, the use of reduced tillage, including no-tillage, has increased.

Although most producers in the Western Cape Province have adopted no-tillage, a few practice strategic tillage by conducting occasional tillage (Findlater et al. 2019), especially in sandy no-tillage fields. Strategic tillage refers to one-off tillage, which is intentionally applied to alleviate specific problems that 
are associated with no-tillage (Blanco-Canqui and Wortmann 2020), inter alia, weed infestation, soil compaction, soil nutrient stratification and to incorporate soil amendments like limestone (Liebenberg et al. 2020; Tshuma et al. 2021). The benefits of strategic tillage have recently been documented (BlancoCanqui and Wortmann 2020; Conyers et al. 2019; Dang et al. 2018; Kirkegaard et al. 2014; Peixoto et al. 2020). Apart from strategic tillage, infrequent tillage could also be considered as an option for alleviating some of the problems associated with no-tillage with the intention of improving crop productivity. Unlike strategic tillage, infrequent tillage is not a one-off practice. There are specific tillage rotations that are followed. Infrequent tillage involves the application of alternating tillage practices (involving tillage and no-tillage) on one specific field. The phase of no-tillage of a particular field can be one, two or three consecutive years which are followed by a year in which tillage is conducted, and then reverting to a phase of no-tillage. Some limited short-term research on infrequent tillage has been conducted in the Western Cape Province (Agenbag 2012; Maali and Agenbag 2003, 2006), however, globally there is a paucity of information on the effects of the long-term infrequent tillage practices on wheat yield.

A long-term tillage study was initiated in the Western Cape Province of South Africa in 1976 to investigate the effects of continuous mouldboard, tine and no-tillage on soil physical and chemical characteristics (Agenbag and Maree 1989) and crop productivity. The infrequent tillage practices were introduced in 1990 to investigate the effects of tillage rotations on soil characteristics and crop productivity (Agenbag 2012).

This research aimed to determine the effects of long-term (44-years) tillage practices on wheat grain yield in a dryland farming system. The objective was to examine and evaluate the long-term wheat grain yield responses from a trial site located at Langgewens Research Farm, in South Africa. It was hypothesised that with time, (i) the monoculture system will lead to reduced wheat grain yield, (ii) continuous ploughing with a mouldboard plough will lead to reduced wheat grain yield, (iii) the infrequent tillage practices will improve wheat grain yield relative to continuous no-tillage.

\section{Materials And Methods}

\section{Trial site description}

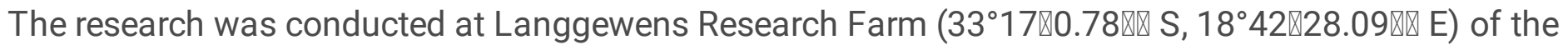
Western Cape Department of Agriculture, in the Swartland region of South Africa (Fig. 1). The Swartland region has a Mediterranean-type climate. The Köppen-Geiger climate classification is Csa (warm temperate climate with hot, dry summer). Langgewens receives an average long-term ( 55 years) annual rainfall of $395 \mathrm{~mm}$ (standard deviation $=101 \mathrm{~mm}$ ), of which approximately $80 \%$ falls during the growing season between April and September.

The trial site has a $300 \mathrm{~mm}$ shallow lithic soil, locally known as a Glenrosa-soil form (Soil Classification Working group 1991) or internationally, as Haplic Cambisols (IUSS Working Group WRB 2015). The soil 
has a $14.7 \%$ clay content (excluding the gravel and stone content), whilst the gravel and stone content in the A horizon is about 45\% (Maali and Agenbag 2003).

\section{Trial history and treatments}

The trial was laid out in a randomised block design with four replicated blocks. Each block had 14 plots and each plot measured $50 \mathrm{~m} \times 6 \mathrm{~m}$. The blocks were separated by a buffer zone of at least $9 \mathrm{~m}$, and plots were separated by a $1 \mathrm{~m}$ buffer zone. Seven tillage treatments were investigated and are summarised in Table 1.

Table 1 Summary of tillage treatments, abbreviation and the implements used

\begin{tabular}{|c|c|c|}
\hline Tillage treatment & Abbreviation & Tools used and tillage intensity \\
\hline Mouldboard & MB & $\begin{array}{l}\text { Ploughing with a chisel (tine) plough to a depth of } 150 \mathrm{~mm} \text {, } \\
\text { followed by the MB plough to a depth of } 200 \mathrm{~mm} \text { and field } \\
\text { cultivator to a depth of } 50 \mathrm{~mm}\end{array}$ \\
\hline Tine-tillage & TT & $\begin{array}{l}\text { Tillage with a chisel plough to a depth of } 150 \mathrm{~mm} \text {, followed by } \\
\text { field cultivator to a depth of } 50 \mathrm{~mm}\end{array}$ \\
\hline Shallow tine-tillage & ST & Tillage with a chisel plough to a depth of $75 \mathrm{~mm}$ \\
\hline No-tillage & NT & Tillage was not conducted. \\
\hline $\begin{array}{l}\text { ST applied every } \\
2^{\text {nd }} \text { year in rotation } \\
\text { with NT }\end{array}$ & ST-NT & $\begin{array}{l}\text { Tillage with a chisel plough to a depth of } 75 \mathrm{~mm} \text { conducted } \\
\text { once every } 2 \text { years. }\end{array}$ \\
\hline $\begin{array}{l}\text { ST applied every } \\
3^{\text {rd }} \text { year in rotation } \\
\text { with NT }\end{array}$ & ST-NT-NT & $\begin{array}{l}\text { Tillage with a chisel plough to a depth of } 75 \mathrm{~mm} \text { conducted } \\
\text { once every } 3 \text { years. }\end{array}$ \\
\hline $\begin{array}{l}\text { ST applied every } \\
4^{\text {th }} \text { year in rotation } \\
\text { with NT }\end{array}$ & ST-NT-NT-NT & $\begin{array}{l}\text { Tillage with a chisel plough to a depth of } 75 \mathrm{~mm} \text { conducted } \\
\text { once every } 4 \text { years. }\end{array}$ \\
\hline
\end{tabular}

Initially, wheat was grown in monoculture on the trial site but in 1990 the long-term trial was split into two cropping systems. One involved continuous wheat (monoculture) production and the other involved the rotation of wheat with lupins and canola. The four-year crop rotation sequences used were continuous wheat (WWWW) and wheat-lupin-wheat-canola (WLWC) (Agenbag 2012; Maali and Agenbag 2006).

Over the years, various sub experiments were conducted within the overall design to explore fertiliser rates. The quantity of fertiliser applied on the trial site therefore varied with time. In summary, $55 \mathrm{~kg} \mathrm{~N} \mathrm{ha}^{-}$ ${ }^{1}$ was applied each season in all plots from 1976 to 1980 . In 1980 and 1982, $65 \mathrm{~kg} \mathrm{~N} \mathrm{ha}^{-1}$ was applied in each plot followed by 80 and $100 \mathrm{~kg} \mathrm{~N} \mathrm{ha}^{-1}$ per plot in 1983 and 1984, respectively. Some $\mathrm{N}$-fertiliser trials conducted in the 1990s required the application of three different levels of fertiliser such that the plots were split into three sections. The sections received 60, 100 and $140 \mathrm{~kg} \mathrm{~N} \mathrm{ha}^{-1}$ and $10 \mathrm{~kg} \mathrm{P} \mathrm{ha}^{-1}$. Liming 
and pesticide applications were conducted as recommended by the research farms' technical committee in line with standard practice for the area at the time.

Instead of wheat, black oats (Avena strigosa) were grown on this trial site in 2011 and 2012 as a means of controlling weeds. In 2013, wheat was also not planted. A variety of cover crops mixtures were, instead, grown on all plots in different species combinations. Ten cover crops species were grown, namely black oats, forage barley (Hordeum vulgare L.), annual ryegrass (Lolium multiflorum), stooling rye (Festuca arundinacea Schreb.), clovers (Trifolium spp.), vetch (Vicia sativa), oat (Avena sativa), mustard (Brassica spp.), triticale (× Triticosecale), and sulla (Hedysarum coronarium).

Tillage was typically conducted after the first autumn rains (usually in April) and seeding was mostly conducted within the first two weeks of May of each year. Grain harvesting was done in October or early November of the same year. The seed varieties that were planted within the trial site changed with time as new, improved varieties became available.

\section{Data analyses}

The Variance Estimation, Precision and Comparison (VEPAC) package of STATISTICA ${ }^{\mathrm{TM}}$ software version 13.5.0.17 (TIBCO Software Inc.) was used to analyse the data using the Restricted Maximum Likelihood (REML) procedure. Tillage sequence, crop management system, plot zone and their interactions were specified as fixed effects. Block was specified as a random effect. All parameters were subjected to a test of normality using the normal probability plots of raw residuals. Also, the Shapiro-Wilk W-test for normality was performed for each variable. Where the F-test was significant, the mean separation was performed using Fisher's least significance difference (LSD) test at a 5\% significance level.

Complete wheat yield data sets were available for four growing seasons 2014, 2016, 2018 and 2020, therefore, statistical analysis was only done on the 2014 to 2020 wheat grain yield data. The wheat grain yield data from 1976 to 2013 was only available as average yield values and thus could not be incorporated for statistical analysis.

Correlation matrices were used to analyse the association between the seasonal rainfall (April to September) and the wheat grain yield for the data from 1996 when the infrequent tillage treatments were started, through to 2020. Scatter plots and coefficient of determination $\left(R^{2}\right)$ were computed for each tillage treatment. Furthermore, scatter plots were also computed for the MB and NT sequences from 1976 to 2020. The long-term wheat grain yield data were summarised and presented as rolling four-year yield averages because the crop rotation system used (WWWW and WCWL) had a four-year cycle.

\section{Results}

\section{Seasonal rainfall and wheat grain yield}


The correlation matrices generally showed a significant $(P<0.05)$ positive association between the seasonal rainfall and wheat grain yield with $\mathrm{R}^{2}$ values that ranged from $21 \%$ in the ST-NT sequence to $37 \%$ in the MB sequence. Thus, less than $38 \%$ of the variation in grain yield can be explained by the variation in seasonal rainfall, for each of the tillage treatments. The scatter plots for the MB and NT sequences are shown in Fig. 2.

Figure 3 shows that the fluctuations in grain yield generally follow the same pattern as seasonal rainfall whereby an increase in seasonal rainfall resulted in an increase in wheat grain yield and vice versa. However, after 2013, a decrease in seasonal rainfall did not result in low grain yield.

\section{Long-term wheat grain yield (1976 - 2020)}

The overall wheat grain yield increased with time across all tillage treatments within both the monoculture and crop rotation systems (Fig. 3). For the monoculture system, there was a sharp yield increase with initial monoculture from 1976 to 1990, then a period of relative yield stasis from 1990 to 2010. For the crop rotation system, there was relative yield stasis from 1990 to 2010 and then a sharp increase again in yields from 2014 to 2020 (Fig. 3). Cover crops were grown for three consecutive years, from 2011 to 2013 on the trial site, therefore there was no wheat grain yield during that period.

There was no distinct pattern in the wheat grain yield due to the tillage sequences. Initially, the wheat grain yield generally decreased and then, over 10 years, consistently increased with an increase in the quantity of $\mathrm{N}$-fertiliser applied. In the early to mid-1990s, the grain yield in the monoculture reached a peak and then declined with time until the monoculture practice was stopped in 2010 (Fig. 3a). The introduction of infrequent tillage practice in 1996 did not lead to an improvement in wheat grain yield but rather a further decline. In almost all the monoculture trial period, the mouldboard (MB) sequence led to the highest wheat grain yield. The no-tillage (NT), tine-tillage (TT) and shallow tine-tillage (ST) all led to higher grain yields than each of the three infrequent tillage treatments. The infrequent tillage ST-NT-NT generally led to the lowest grain yield in the wheat monoculture system.

Although the wheat grain yields fluctuated with time, the introduction of the crop rotation system in the 1990 s led to an increase in the wheat grain yield (Fig. 3b). From the inception of the crop rotation system (in 1990) to 1997, the NT, TT and MB led to relatively similar grain yields. From 1997 to 2009, the NT sequence treatment led to higher grain yields, closely followed by the TT sequence treatment. The grain yield then substantially increased from 2014 to 2020 across all tillage treatments. After 2018, all tillage treatments except the ST-NT sequence led to grain yields greater $(P>0.05)$ than that in the MB sequence. The three infrequent tillage sequences generally resulted in lower grain yields than all other tillage treatments but improved with time. The ST-NT sequence, however, consistently resulted in the lowest grain yield from 2004 until 2020.

\section{Wheat grain yield - 2014 to 2020}


In 2014 and 2016, the tillage sequence treatments affected $(P<0.05)$ the wheat grain yield (Fig. 4). Despite the long period (44 years) of continuous intensive tillage with the MB plough, the wheat grain yield in the MB sequence was highest in both 2014 and 2016 but not in 2018 and 2020. Except in 2020 when the MB resulted in the lowest $(P>0.05)$ yield, the ST-NT sequence consistently led to the lowest wheat grain yields in all years. Compared to 2014, the wheat grain yield was generally greater in 2016 , 2018 and 2020. In 2020, the wheat grain yield was more than $4000 \mathrm{~kg} \mathrm{ha}^{-1}$ in all tillage treatments, except in the MB sequence.

In 2014, the MB tillage sequence had the highest $(P<0.05)$ grain yield $\left(3210 \mathrm{~kg} \mathrm{ha}^{-1}\right)$ whilst the rest of the tillage sequence treatments did not differ $(P>0.05)$ from each other (Fig. 4a). Although not always significant, the infrequent tillage sequences ST-NT and ST-NT-NT led to the lowest yield in both 2014 and 2016. In contrast, the infrequent tillage sequence ST-NT-NT-NT led to grain yields that were similar $(P>0.05)$ to the highest yielding treatments, including the NT sequence in 2016.

Although the grain yield did not differ $(P>0.05)$ between the MB, TT, ST, NT and ST-NT-NT-NT treatments, the MB sequence resulted in the highest yield in 2016 with $3880 \mathrm{~kg} \mathrm{ha}^{-1}$ (Fig. 4b). The ST-NT sequence had the lowest $(P<0.05)$ wheat grain yield $\left(3165 \mathrm{~kg} \mathrm{ha}^{-1}\right)$ but did not differ $(P>0.05)$ from that of the STNT-NT sequence. Furthermore, the infrequent tillage sequence ST-NT-NT led to a slightly greater wheat grain yield but did not significantly differ from that of the NT sequence.

In 2018 and 2020, there were no differences $(P>0.05)$ in wheat grain yield between any tillage treatments (Fig. 4c and d, respectively). The ST-NT sequence resulted in the lowest $(P>0.05)$ grain yield (3172 kg ha-

${ }^{1}$ ) in 2018 whilst the ST-NT-NT sequence had the highest grain yield with $4338 \mathrm{~kg} \mathrm{ha}^{-1}$. In 2020, the MB sequence led to the lowest grain yield $\left(3645 \mathrm{~kg} \mathrm{ha}^{-1}\right)$ whilst the NT sequence had the highest $(P>0.05)$ yield $\left(4423 \mathrm{~kg} \mathrm{ha}^{-1}\right)$.

\section{Discussion}

\section{Effects of seasonal rainfall on wheat grain yield}

Our results concerning the relationship between seasonal rainfall (April to September) and wheat grain yield were similar to the findings by Kloppers (2014) who studied the relationship between winter rainfall and wheat grain yield in the Swartland region. Using rainfall and yield data from 1994 to 2010, Kloppers (2014) found Pearson's correlation coefficient ( $r$ ) values that ranged between 0.424 and 0.522 (or $R^{2}$ values between 18 and 27\%). Also similar to our results, Crookes et al. (2017) stated that seasonal rainfall from 1996 to 2015 had a positive relationship with wheat grain yield at Langgewens Research Farm. In our study, the relationship between seasonal rainfall and wheat grain yield ( $R^{2}$ values) show that other factors may have affected the wheat grain yields in the Swartland region. For example, yield can be affected by the seed variety, available soil water (Schillinger et al. 2008), distribution of the rainfall (Kloppers 2014), environmental temperature (Gooding et al. 2003) and soil tillage, amongst other things. Water availability is crucial during the grain filling phase and can affect grain yield (Abid et al. 
2017). In the Swartland region, grain filling mostly occurs in September, therefore, a good amount of available stored soil water or rainfall in September is needed for a higher grain yield.

The positive correlation between the long-term seasonal rainfall and wheat grain yield could be part of the reason why the grain yield increased or decreased with an increase or decrease in seasonal rainfall (Fig. 3). The effects of seasonal rainfall on grain yield may have contributed to the differences in grain yield in 2014 and 2016 (Fig. 4a and b). The 2016 growing season had higher seasonal rainfall, with 319 mm compared to $278 \mathrm{~mm}$ in 2014, and generally had a greater grain yield than that obtained in 2014. In both years, the monthly rainfall during the growing season was greater than $35 \mathrm{~mm}$, except for April and September 2014, and May 2016 which had 16.8, 13.2 and $4.0 \mathrm{~mm}$, respectively.

The introduction and use of improved seed varieties could, inter alia, have also led to increased grain yield especially after 2014 when a decrease in rainfall did not lead to a decrease in grain yield. Furthermore, the 2020 growing season had relatively less seasonal rainfall (306 mm) than 2018 (326 $\mathrm{mm})$ and $2016(319 \mathrm{~mm})$ but generally had relatively similar or greater grain yields than that of 2018 and 2016 (Fig. 4 (b), (c) and (d). There is little difference between the three rainfall values, suggesting that the observed differences in yield between these time points cannot be explained by rainfall alone but also by the use of improved herbicides, pesticides and seed varieties. Nhemachena and Kirsten (2017) noted that the improvements in seed varieties in South Africa was slow but contributed to increased wheat grain production with time. Tadesse et al. (2018) noted that the wheat varieties grown in South Africa were mostly derived from crosses that were slowly made within the country, therefore, progress was slow. In addition, the substantial increase in wheat grain yield across all tillage treatments could also be attributed to the positive effects of growing cover crops for three consecutive years within this trial site. Smit et al. (2021) noted that the use of cover crop mixtures can increase soil available nitrogen and can lead to increased productivity of the following crops.

\section{Effects of growing wheat in a monoculture system}

The evaluation of the long-term wheat monoculture data shows that there was an initial decrease in wheat grain yield from the inception of the trial (in 1976) to 1980, followed by a general increase from 1980 to 1990 (Fig. 3a). The increase in the wheat grain yield coincides with rising $\mathrm{N}$-fertiliser application. It is therefore plausible that the initial decrease in yield could have been because of the poor supply of nitrogen. The increments in $\mathrm{N}$-fertiliser applications were only implemented after 1980 . These results are similar to those obtained by (Agenbag 2012; Litke et al. 2018; Maali and Agenbag 2003; Tabak et al. 2020) who stated that the grain yield increased with an increase in $\mathrm{N}$-fertiliser application.

Long-term trials have some limitations in that they have a propensity to have some variables changed with time, such that a proper analysis of results may be negatively impacted. Chmielewski and Potts (1995) and a report by Rothamsted Research (2012) shows that the long-term trials at Rothamsted Research Farm in the UK underwent some adjustments with the addition or removal of fertilisers and division of fields into different sections to enable fallowing. Likewise, several adjustments were made within our trial site over the years. For example, wheat was not grown for three consecutive years from 
2011 to 2013 to control weeds. Also, the monoculture system within our trial site was ended in 2010 as the production costs increased along with an increased build-up of weeds as stated by Dube et al., (2020) and Swanepoel et al., (2016). Previous studies conducted within this long-term trial site during 2008 and 2010 by Agenbag (2012) shows that the wheat monoculture fields were severely infested by herbicideresistant ryegrass which led to reduced grain yield. An evaluation of a crop rotation study which was initiated in 2007 at two different locations in the Mediterranean climate region of South Africa, namely, Langgewens Research Farm (in the Swartland region) and Tygerhoek Research Farm (in the Southern Cape region) also showed that the wheat monoculture system resulted in more weeds than in the crop rotation system (MacLaren et al. 2021). Likewise, in Poland, an evaluation of a 29-year-old cereal monoculture system by Woźniak, (2019) showed that the monoculture system resulted in lower wheat grain yield and quality when compared to a crop rotation system. Woźniak, $(2020,2019)$ attributed the reduced yield to increased weed and disease infestation.

\section{Effects of growing wheat in a crop rotation system}

In agreement with other studies (Nhemachena and Kirsten 2017; Woźniak 2019, 2020), the crop rotation system in this long-term research led to increased wheat grain yield relative to the monoculture system (Fig. 3). From 1989 to 2009, there was relatively little difference between wheat grain yield from the monoculture and crop rotation systems. However, after 2010, the differences became pronounced. The increase in wheat grain yields in the long-term research could be because of a variety of factors inter alia, improved seed cultivars, farm management practices, herbicides, fungicides, pesticides and farming implements (Findlater et al. 2018). In a review of commercial wheat production and breeding in South Africa, Nhemachena and Kirsten (2017) found that dryland wheat productivity increased from less than $500 \mathrm{~kg} \mathrm{ha}^{-1}$ in 1936 to more than $3500 \mathrm{~kg} \mathrm{ha}^{-1}$ in 2015, partly as a result of sowing improved seed cultivars. However, the dryland wheat grain yields in South Africa are lower than that of the major wheatproducing countries in the world due, amongst other things, to the slower wheat breeding progress in South Africa (Nhemachena and Kirsten 2017; Tadesse et al. 2018).

The introduction of crop rotation enabled the use of different specific herbicides which could not be used in the monoculture system (MacLaren et al. 2021). For example, when triazine herbicides, which could not be applied in wheat monoculture, were introduced in 2005 in the canola phase of the crop rotation system, there was a marked improvement in wheat grain yield in the season that followed. The inclusion of legumes in the crop rotation system probably increased the soil nitrogen content (Das et al. 2018) and availability for crops, leading to improved crop yields. Also, the crop rotation system enabled better control of weeds and pests by disrupting the weed and pest life cycles (Schillinger and Paulitz 2018). Regardless of the positive effects of using different herbicides in the crop rotation system from 2005 to 2010, the grain yield did not increase as much as it did from 2014 to 2020. We believe that the three years of continuous cover crops from 2011 to 2013 could have contributed to the difference in grain yields.

\section{Effects of the mouldboard plough on wheat grain yield}


Frequent, intensive tillage with implements such as the mouldboard and disc ploughs have been identified as major contributors to soil degradation through the depletion of soil organic carbon (Tshuma et al. 2021) and erosion of the fertile topsoil (Dendooven et al., 2012; Derpsch, 2004; Hobbs et al., 2008; Swanepoel et al., 2015) and increased greenhouse gas emission due to both the burning of extra fossil fuel and emissions from the soil (Rutkowska et al. 2018; Carbonell-Bojollo et al. 2019). Soil degradation may lead to reduced crop productivity, however, in this research, intensive tillage with the MB plough led to the opposite. This long-term research shows that the MB sequence generally resulted in the highest yields (although not always significantly different) in the wheat monoculture rather than in the crop rotation systems (Fig. 3a and b). A separate long-term trial initiated in 1996, also at Langgewens Research Farm, showed that the average wheat yields under no-tillage, from 2002 to 2012 were 2890 and $3790 \mathrm{~kg} \mathrm{ha}^{-1}$ in the wheat monoculture and crop rotation, respectively (Strauss and Hardy 2014). A report by the ARC-Small Grain Institute (2020) shows that the average wheat yield under no-tillage in the Swartland region is $3220 \mathrm{~kg} \mathrm{ha}^{-1}$. The MB sequence in our trial resulted in yields that were generally greater than $2000 \mathrm{~kg} \mathrm{ha}^{-1}$ in the early 1990s and started to steadily increase in 2005 to yield more than $2500 \mathrm{~kg} \mathrm{ha}^{-1}$ (Fig. 3b). Higher yields in conventional tillage with MB plough, relative to no-tillage practices were also observed by Maali and Agenbag (2003) and other researchers across the globe (Pittelkow et al. 2015; Litke et al. 2018).

Tillage with the MB plough enables the soil to warm faster (Shen et al. 2018) which may improve crop establishment and the subsequent yield, especially in areas that are prone to freezing temperatures. The Swartland region is, however, not prone to freezing temperatures, therefore, the effects of tillage on soil temperature could be negligible at this long-term research site. Rather, the effects of tillage on soil aeration and nutrient mineralisation could have contributed to higher grain yield as more nutrients become available for plant uptake (Blevins and Frye 1993). Also, the MB sequence may result in higher yields when there is adequate soil moisture (Maali and Agenbag 2003). The MB plough is also an effective means of controlling weeds (Lal et al. 2007; MacLaren et al. 2021) when compared to other tillage treatments, aiding with improved crop productivity. Similar to our results, Seepamore et al. (2020) found that the grain yield can increase with increased tillage intensity. Although tillage with the MB can lead to increased soil nutrient mineralisation and increased crop productivity, it ultimately leads to reduced soil organic carbon stocks (Dendooven et al. 2012; Swanepoel et al. 2015; Tshuma et al. 2021) increased greenhouse gas emissions (Carbonell-Bojollo et al. 2019; Rutkowska et al. 2018) from the soil and can increase the chances of soil erosion. In this research, the MB sequence led to reduced $(P>0.05)$ grain yield relative to other tillage sequences in the crop rotation system from 2016 onwards. More growing seasons are necessary to observe if the grain yield in the MB treatment will continue to decline, which would be indicative of the long-term negative effects of intensive tillage on crop productivity.

\section{Effects of the infrequent tillage on wheat grain yield}

The infrequent tillage treatments, which were expected to alleviate some of the problems associated with NT, failed to improve the wheat grain yield relative to the NT treatment in both the monoculture and crop 
rotation systems in this long-term trial. Wheat grain yield was generally greater in the MB sequence (although not always significantly so) whilst the ST-NT sequence gave the lowest yields (again, not always significantly different). Earlier studies within this long-term trial site between 2002 and 2010 also had similar results in that there were no significant differences in wheat grain yield between the infrequent tillage sequences and the NT sequence (Agenbag 2012). In our trial, it took 18 years (1996 to 2014) for the infrequent tillage sequence ST-NT-NT-NT to equal the rolling 4-year grain yield of the NT sequence, and a further four years for the infrequent tillage sequence ST-NT-NT (Fig. 3b). The ST-NT sequence generally was the odd one as it led to lower yields.

Literature on infrequent tillage is limited, therefore an assessment of occasional or strategic tillage could be beneficial. A literature review of 30 strategic tillage studies across the world revealed that for a period of two to three years after the strategic tillage, crop yield did not significantly change from that of the NT treatment in $80 \%$, decreased in $5 \%$ and increased in about $15 \%$ of the cases (Blanco-Canqui and Wortmann 2020). Likewise, several other studies on strategic tillage (Conyers and Dang 2014; Dang et al. 2018; Kirkegaard et al. 2014) have also indicated that crop yield was, in most cases, neither improved nor decreased. Although the infrequent tillage practices can help to incorporate soil amendments (Tshuma et al. 2021), the results presented in this paper indicate that crop yield was not significantly increased by the infrequent tillage practices relative to the NT treatment. A study of the soil chemical characteristics within this trial site by Tshuma et al. (2021) found that the infrequent tillage sequence ST-NT-NT-NT sequence did not significantly reduce nutrient stratification relative to the NT sequence. Likewise, wheat grain yield did not differ significantly between the two tillage treatments.

Although the grain yield in the infrequent tillage sequence ST-NT-NT-NT steadily increased with time until it equalled the yield in the NT sequence, the added tillage increases production costs (Blanco-Canqui and Wortmann 2020) such that the overall yield benefit may be negligible when compared to the NT practice.

In summary, the substantial increase in grain yield across all tillage treatments from 2014 to 2020 shows that there are factors other than tillage that affected the long-term wheat grain yield. Amongst other things, the use of improved seed varieties, cover crop mixtures, increased fertiliser rates, herbicides, insecticides, and fungicides could have contributed to increased grain yields. Also, the relatively high yield in the MB sequence in this long-term research does not imply that the practice was the best or most sustainable or profitable. The use of a mouldboard plough generally requires several passes in the field, which leads to the use of more fuel, time and labour when compared to the reduced tillage practices (Govaerts et al. 2009; Taner et al. 2015) such as NT or the infrequent tillage (Table 2).

Table 2 The fuel and cost (excluding labour and time) of land preparation through the MB and ST-NT-NTNT sequences at Langgewens Research Farm. The data is based on a 206 kW 4-wheel-drive tractor data credit: Western Cape Department of Agriculture - South Africa. The monetary values were converted to US\$ at the prevailing exchange rate of US\$1 $=13.42$ South African Rand, as of 04 June 2021 
Operations

Fuel ( $\left(h^{-1} a^{-1}\right) \quad$ Cost (US\$ ha-1)

The no-tillage sequence (NT)

\begin{tabular}{|lll|}
\hline Pre-plant herbicide application & 14.48 & 14.28 \\
\hline Tillage & 0.00 & 0.00 \\
\hline Total (per year) & $\mathbf{1 4 . 4 8}$ & $\mathbf{1 4 . 2 8}$ \\
\hline Total (per 4-year period) & $\mathbf{5 7 . 9 2}$ & $\mathbf{5 7 . 1 2}$ \\
\hline The infrequent tillage sequence (ST-NT-NT-NT) & \\
\hline Pre-plant herbicide application & 14.48 & 14.28 \\
\hline Shallow tine-tillage (75 mm; Once in 4-years) & 21.72 & 21.42 \\
\hline Total (per year, when tillage is conducted) & $\mathbf{3 6 . 2 0}$ & $\mathbf{3 5 . 7 0}$ \\
\hline Total (per 4-year period) & $\mathbf{7 9 . 6 4}$ & $\mathbf{7 8 . 5 4}$ \\
\hline The mouldboard sequence (MB) & & \\
\hline Chisel plough (150 mm depth) & 32.58 & 32.12 \\
\hline MB plough (200 mm depth) & 37.23 & 36.71 \\
\hline Field cultivator (50 mm) & 17.37 & 17.13 \\
\hline Total (per year) & $\mathbf{8 7 . 1 8}$ & $\mathbf{8 5 . 9 6}$ \\
\hline Total (per 4-year period) & $\mathbf{3 4 8 . 7 2}$ & $\mathbf{3 4 3 . 8 4}$ \\
\hline
\end{tabular}

The data provided in Table 2 is based on a $206 \mathrm{~kW}$ tractor but can be applied to any other tractor as the overall differences in fuel consumption, time and labour are expected to be similar. Any tractor would consume more fuel when conducting a heavier task (Adewoyin and Ajav 2013; Bertonha et al. 2015), such as pulling a mouldboard plough at a depth of $200 \mathrm{~mm}$ compared to the same tractor pulling a field cultivator at a depth of $50 \mathrm{~mm}$.

In this research, the MB sequence required three passes before each planting season, and a total of 12 pre-plant passes in four years. The infrequent tillage sequence ST-NT-NT-NT required two pre-plant passes during the year in which tillage was conducted, followed by three years of no-tillage but with one pre-plant pass per year involving the spraying of pre-plant herbicides. In a four-year cycle, a total of five pre-plant passes were conducted in the infrequent tillage sequence ST-NT-NT-NT. The NT sequence had no tractor pass involving tillage and had a total of four pre-plant passes involving the application of pre-plant herbicides in a four-year cycle.

Management practices such as planting and post-planting herbicides, fertilisers and pesticides application largely contributed to grain yield but were constant across all the treatments and were not considered in the analysis of operational costs. The cost and time demand for the land preparation is 
greater in the MB tillage treatment than in the NT and ST-NT-NT-NT tillage sequences but were not considered in operational cost analysis in Table 2.

An analysis of fuel consumption and cost related to land preparation before planting is thus used to show that for this research, in the first year of a four-year cycle alone, the MB sequence can use $502 \%$ and $141 \%$ more fuel than the NT and infrequent tillage sequence ST-NT-NT-NT treatments, respectively. In a four-year tillage cycle, the fuel cost and use can each be $502 \%$ and $338 \%$ more in the MB treatment than in the NT and ST-NT-NT-NT sequence treatments, respectively. Since the grain yield in the MB sequence was not always significantly higher than the NT and ST-NT-NT-NT sequences, it is plausible to conclude that the NT and the infrequent tillage sequence ST-NT-NT-NT, were more profitable than the MB sequence.

It is important to note that the local commercial farmers usually apply more than one pre-plant herbicide in their NT fields, therefore, the amount of fuel used, and overall costs can be somewhat higher than the figures presented in Table 2.

Conventional tillage with the MB plough is not environmentally sustainable as it can increase carbon dioxide emissions by more than $50 \%$ when compared to reduced tillage practices (Carbonell-Bojollo et al. 2019; Rutkowska et al. 2018). Furthermore, a recent soil analysis of this long-term trial site by Tshuma et al. (2021) revealed that soil quality in the MB treatment was deteriorating as it had the least $(P<0.05)$ soil organic carbon stocks, extractable phosphorus stocks and a soil organic carbon stratification ratio of 1.1. (Franzluebbers 2002) stated that soil organic carbon stratification ratios which are less than two are indicative of soils of poor quality. The low soil quality could be indicative that continued intensive tillage with the mouldboard plough could eventually lead to reduced wheat grain yield as some nutrients become limiting.

\section{Conclusions}

Our results broadly show that the long-term wheat grain yield was affected by a variety of factors, inter alia, use of improved seed varieties, fertiliser applications, different herbicides, growing of cover crops, seasonal rainfall and tillage. Wheat grain yield was generally higher in the crop rotation system than in the monoculture system. The wheat grain production costs in the monoculture system increased with time and were not sustainable. The monoculture portion of the long-term trial was subsequently discontinued. Compared to other tillage treatments in the monoculture system, the MB sequence led to relatively higher yields, however, in the crop rotation system, the NT treatment was the better option. Although ploughing with the MB led to high yields, it was not the most financially cost-effective treatment overall. Ploughing with the MB may lead to increased soil erosion, greenhouse gas emission, global warming, and depletion of soil organic carbon. Our results show that the infrequent tillage sequences did not significantly increase the wheat grain yield when compared to the NT sequence, therefore, the NT sequence was the overall better option.

We recommend that wheat producers opt for NT and crop rotation to ensure sustainability and avoid intensive tillage. 


\section{Declarations}

\section{Acknowledgements}

The Western Cape Department of Agriculture, Coventry University and Stellenbosch University are acknowledged for funding the long-term trials within which this study was conducted. We thank the Western Cape Agricultural Research Trust for providing the research bursary and the Western Cape Department of Agriculture staff for their work in maintaining these trials and assisting with data collection. We gratefully acknowledge Dr Johann Strauss (Western Cape Department of Agriculture, Elsenburg) for proofreading and editing this article.

\section{Conflict of interest}

The authors declare that they have no conflict of interest.

\section{Availability of data and material}

Not applicable.

\section{Code availability}

Not applicable.

\section{Authors' contribution}

$\mathrm{PS}, \mathrm{JL}, \mathrm{FR}$ and JB contributed to the study conception and design. FT conducted the research under the guidance of PS, JL, FR and JB. FT drafted the initial manuscript. PS, JL, FR and JB edited the manuscript. All authors read and approved the final manuscript.

\section{References}

Abid M, Shao Y, Liu S, et al (2017) Pre-drought priming sustains grain development under post-anthesis drought stress by regulating the growth hormones in winter wheat (Triticum aestivum L.). Planta 246:509-524. doi: 10.1007/s00425-017-2698-4

Adewoyin AO, Ajav EA (2013) Fuel consumption of some tractor models for ploughing operations in the sandy-loam soil of Nigeria at various speeds and ploughing depths. Agric Eng Int CIGR J 15:67-74

Agenbag GA (2012) Growth, yield and grain protein content of wheat (Triticum aestivum L.) in response to nitrogen fertiliser rates, crop rotation and soil tillage. South African J Plant Soil 29:73-79. doi: $10.1080 / 02571862.2012 .716457$

Agenbag GA, Maree PCJ (1989) The effect of tillage on soil carbon, nitrogen and soil strength of simulated surface crusts in two cropping systems for wheat (Triticum aestivum). Soil Tillage Res 14:53- 
65. doi: 10.1016/0167-1987(89)90020-2

ARC-Small Grain Institute (2020) Guideline: Production of small grains in the winter rainfall area. Bethlehem, South Africa

Bertonha RS, Furlani CEA, Silva VFA, Chioderoli CA (2015) Fuel demand as a function of furrow opener and soil conditions in no-tillage system. African J Agric Res 10:1266-1272. doi:

10.5897/AJAR2014.8788

Blanco-Canqui H, Wortmann CS (2020) Does occasional tillage undo the ecosystem services gained with no-till? A review. Soil Tillage Res 198:104534. doi: 10.1016/j.still.2019.104534

Blevins RL, Frye WW (1993) Conservation tillage: An ecological approach to soil management. In: Advances in Agronomy. Academic Press, pp 33-78

Carbonell-Bojollo R, Veroz-Gonzalez O, Ordoñez-Fernandez R, et al (2019) The effect of conservation agriculture and environmental factors on $\mathrm{CO} 2$ emissions in a rainfed crop rotation. Sustain 11:1-19. doi: $10.3390 /$ su11143955

Chmielewski FM, Potts JM (1995) The relationship between crop yields from an experiment in southern England and long-term climate variations. Agric For Meteorol 73:43-66. doi: 10.1016/01681923(94)02174-I

Conyers M, Dang Y (2014) Strategic tillage - Is there room for strategic tillage in a no-till system?

Conyers M, Dang YP, Kirkegaard J (2019) Strategic tillage within conservation agriculture. In: Pratley J, Kirkegaard J (eds) Australian agriculture in 2020: from conservation to automation. Agronomy Australia and Charles Sturt University, Wagga Wagga, pp 107-115

Crookes D, Strauss J, Blignaut JN (2017) The effect of rainfall variability on sustainable wheat production under no-till farming systems in the Swartland region, South Africa. African J Agric Resour Econ 12:62-84. doi: 10.22004/ag.econ.258600

Dang YP, Balzer A, Crawford M, et al (2018) Strategic tillage in conservation agricultural systems of northeastern Australia: why, where, when and how? Environ Sci Pollut Res 25:1000-1015. doi:

10.1007/s11356-017-8937-1

Das A, Lyngdoh D, Ghosh PK, et al (2018) Tillage and cropping sequence effect on physico-chemical and biological properties of soil in Eastern Himalayas, India. Soil Tillage Res 180:182-193. doi: 10.1016/j.still.2018.03.005

Dendooven L, Gutiérrez-Oliva VF, Patiño-Zúñiga L, et al (2012) Greenhouse gas emissions under conservation agriculture compared to traditional cultivation of maize in the central highlands of Mexico. Sci Total Environ 431:237-244. doi: 10.1016/J.SCITOTENV.2012.05.029 
Derpsch R (2004) History of crop production, with and without tillage. Lead Edge 3:150-154

Dube E, Tsilo TJ, Sosibo NZ, Fanadzo M (2020) Irrigation wheat production constraints and opportunities in South Africa. S Afr J Sci 116:1-6. doi: 10.17159/sajs.2020/6342

FAO (2010) Farming for the future in southern Africa: An introduction to conservation agriculture. REOSA Tech. Br. 1-4

Findlater KM, Kandlikar M, Satterfield T (2019) Misunderstanding conservation agriculture: Challenges in promoting, monitoring and evaluating sustainable farming. Environ Sci Policy 100:47-54. doi:

10.1016/j.envsci.2019.05.027

Findlater KM, Satterfield T, Kandlikar M, Donner SD (2018) Six languages for a risky climate: how farmers react to weather and climate change. Clim Change 148:451-465. doi: 10.1007/s10584-018-2217-z

Franzluebbers A. (2002) Soil organic matter stratification ratio as an indicator of soil quality. Soil Tillage Res 66:95-106. doi: 10.1016/S0167-1987(02)00018-1

Gooding MJ, Ellis RH, Shewry PR, Schofield JD (2003) Effects of restricted water availability and increased temperature on the grain filling, drying and quality of winter wheat. J Cereal Sci 37:295-309. doi: $10.1006 /$ jcrs.2002.0501

Govaerts B, Verhulst N, Castellanos-Navarrete A, et al (2009) Conservation agriculture and soil carbon sequestration: Between myth and farmer reality. CRC Crit Rev Plant Sci 28:97-122. doi:

$10.1080 / 07352680902776358$

Hobbs PR, Sayre K, Gupta R (2008) The role of conservation agriculture in sustainable agriculture. Philos Trans R Soc B Biol Sci 363:543-555. doi: 10.1098/rstb.2007.2169

IUSS Working Group WRB (2015) World reference base for soil resources 2014, update 2015 International soil classification system for naming soils and creating legends for soil maps. FAO, Rome

Kirkegaard JA, Conyers MK, Hunt JR, et al (2014) Sense and nonsense in conservation agriculture: Principles, pragmatism and productivity in Australian mixed farming systems. Agric Ecosyst Environ 187:133-145. doi: 10.1016/j.agee.2013.08.011

Kloppers P-L (2014) Investigating the relationships between wheat-specific rainfall characteristics, largescale modes of climate variability and wheat yields in the Swartland region, South Africa. University of Cape Town, South Africa

Lal R, Reicosky DC, Hanson JD (2007) Evolution of the plow over 10,000 years and the rationale for no-till farming. Soil Tillage Res 93:1-12. doi: 10.1016/j.still.2006.11.004 
Liebenberg A, van der Nest JR (Ruan), Hardie AG, et al (2020) Extent of soil acidity in no-tillage systems in the Western Cape Province of South Africa. Land 9:1-17. doi: 10.3390/land9100361

Litke L, Gaile Z, Ruža A (2018) Effect of nitrogen fertilization on winter wheat yield and yield quality. Agron Res 16:500-509. doi: 10.15159/AR.18.064

Maali SH, Agenbag GA (2006) Effect of soil tillage, crop rotation and nitrogen application rates on breadbaking quality of spring wheat (Triticum aestivum L.) in the Swartland wheat producing area of South Africa. South African J Plant Soil 23:163-168. doi: 10.1080/02571862.2006.10634749

Maali SH, Agenbag GA (2003) Effect of soil tillage, crop rotation and nitrogen application rates on grain yield of spring wheat (Triticum aestivum L.) in the Swartland wheat producing area of the Republic of South Africa. South African J Plant Soil 20:111-118. doi: 10.1080/02571862.2003.10634919

MacLaren C, Labuschagne J, Swanepoel PA (2021) Tillage practices affect weeds differently in monoculture vs. crop rotation. Soil Tillage Res 205:1-11. doi: 10.1016/j.still.2020.104795

Nhemachena CR, Kirsten J (2017) A historical assessment of sources and uses of wheat varietal innovations in South Africa. S Afr J Sci 113:1-8. doi: 10.17159/sajs.2017/20160008

Peixoto DS, Silva L de CM da, Melo LBB de, et al (2020) Occasional tillage in no-tillage systems: A global meta-analysis. Sci Total Environ 745:140887. doi: 10.1016/j.scitotenv.2020.140887

Pittelkow CM, Linquist BA, Lundy ME, et al (2015) When does no-till yield more? A global meta-analysis. F Crop Res 183:156-168. doi: 10.1016/j.fcr.2015.07.020

Rayns F, Rosenfeld A, Schmutz U, Rahn C (2010) Green manures - implications of economic and environmental benefits on rotational management. Horticulture Development Company, Factsheet 26/10

Rothamsted Research (2012) Rothamsted Research: Guide to the classical and other long-term experiments, datasets and sample archive. Harpenden, Hertfordshire, UK

Rutkowska B, Szulc W, Sosulski T, et al (2018) Impact of reduced tillage on C02 emission from soil under maize cultivation. Soil Tillage Res 180:21-28. doi: 10.1016/j.still.2018.02.012

Schillinger WF, Paulitz TC (2018) Canola versus wheat rotation effects on subsequent wheat yield. F Crop Res 223:26-32. doi: 10.1016/j.fcr.2018.04.002

Schillinger WF, Schofstoll SE, Alldredge JR (2008) Available water and wheat grain yield relations in a Mediterranean climate. F Crop Res 109:45-49. doi: 10.1016/j.fcr.2008.06.008

Seepamore MK, du Preez CC, Ceronio GM (2020) Impact of long-term production management practices on wheat grain yield and quality components under a semi-arid climate. South African J Plant Soil 37:194-201. doi: 10.1080/02571862.2020.1741707 
Shen Y, Mclaughlin N, Zhang X, et al (2018) Effect of tillage and crop residue on soil temperature following planting for a Black soil in Northeast China. Sci Rep 8:1-9. doi: 10.1038/s41598-018-22822-8

Smit EH, Strauss JA, Swanepoel PA (2021) Utilisation of cover crops: implications for conservation agriculture systems in a Mediterranean climate region of South Africa. Plant Soil 462:207-218. doi: $10.1007 / \mathrm{s} 11104-021-04864-6$

Soil Classification Working group (1991) Soil classification: A taxonomic system for South Africa. Memoirs on the Agricultural Natural Resources of South Africa No. 15.

Strauss JA, Hardy M (2014) An investigation into the production dynamics of eight crop rotation systems including wheat, canola, lupins and pasture species in the Swartland, Western Cape. Cape Town, South Africa

Swanepoel PA, Botha PR, du Preez CC, et al (2015) Managing cultivated pastures for improving soil quality in South Africa: challenges and opportunities. African J Range Forage Sci 32:91-96. doi: $10.2989 / 10220119.2015 .1051112$

Swanepoel PA, Labuschagne J, Hardy MB (2016) Historical development and future perspective of conservation agriculture practices in crop-pasture rotation systems in the Mediterranean region of South Africa. In: Kyriazopoulos A., Lopez-Francos A, Porquedu C, Sklavou P (eds) Ecosystem services and socioeconomic benefits of Mediterranean grasslands. Zaragoza. Options Méditerranéennes. Series A: Mediterranean Seminars, No. 114, Paris: Centre International de Hautes Etudes Agronomiques Méditerranéennes., pp 75-78

Tabak M, Lepiarczyk A, Filipek-mazur B, Lisowska A (2020) Efficiency of nitrogen fertilization of winter wheat depending on sulfur fertilization. Agronomy 10:1-17

Tadesse W, Bishaw Z, Assefa S (2018) Wheat production and breeding in Sub-Saharan Africa Challenges and opportunities in the face of climate change. Int J Clim Chang Strateg Manag 11:696715. doi: 10.1108/IJCCSM-02-2018-0015

Taner A, Arisoy RZ, Kaya Y, et al (2015) The effects of various tillage systems on grain yield, quality parameters and energy indices in winter wheat production under the rainfed conditions. Fresenius Environ Bull 24:1463-1473

Tshuma F, Rayns F, Labuschagne J, et al (2021) Effects of long-term (42 years) tillage sequence on soil chemical characteristics in a dryland farming system. Soil Tillage Res 212:1-9. doi:

10.1016/j.still.2021.105064

Udall D, Rayns F, Mansfield T (2014) Living soils: A call to action. Soil Association/ Coventry University, Bristol/ Coventry 
Woźniak A (2020) Effect of cereal monoculture and tillage systems on grain yield and weed infestation of winter durum wheat. Int J Plant Prod 14:1-8. doi: 10.1007/s42106-019-00062-8

Woźniak A (2019) Effect of crop rotation and cereal monoculture on the yield and quality of winter wheat grain and on crop infestation with weeds and soil properties. Int J Plant Prod 13:177-182

\section{Figures}

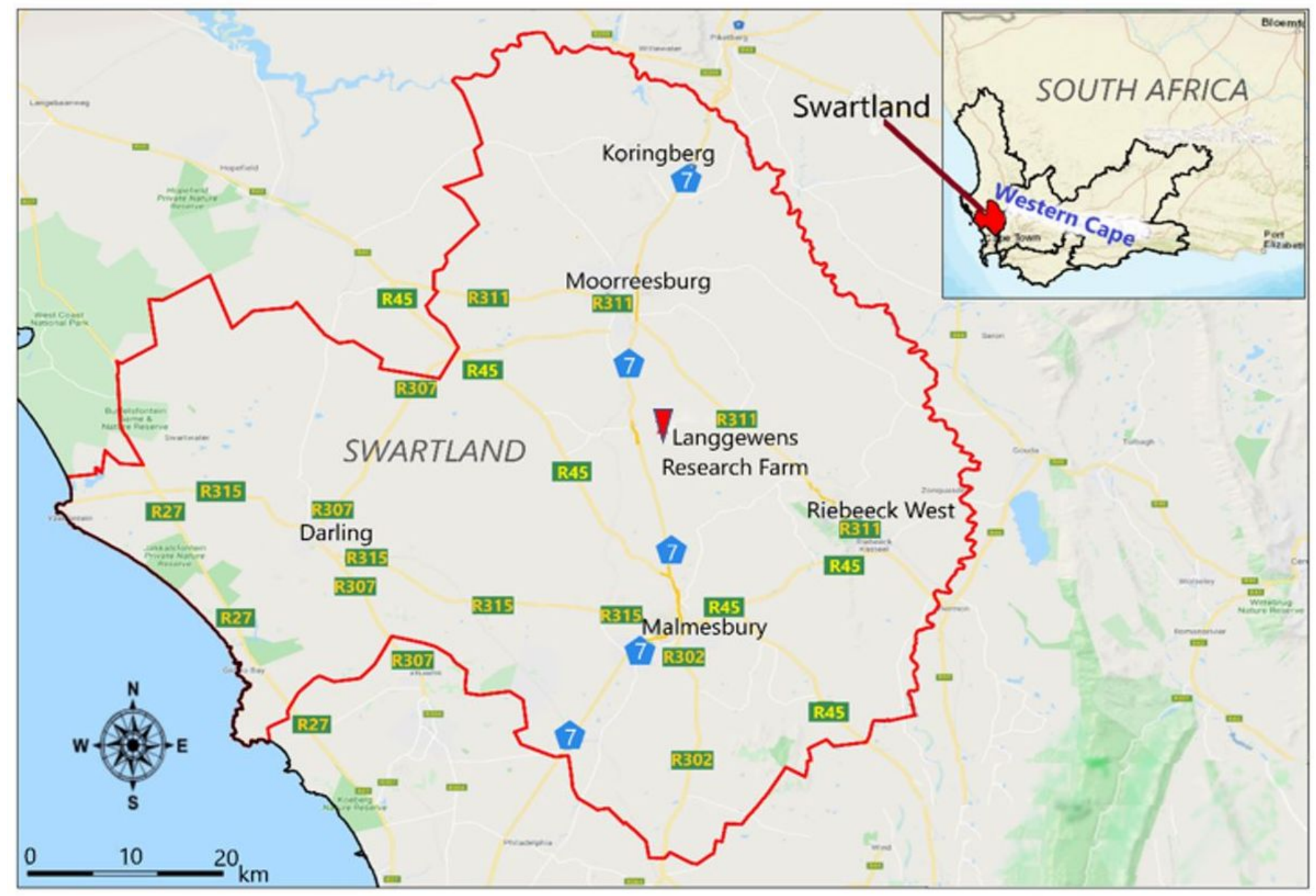

Figure 1

The location of Langgewens Research Farm in the Swartland region, in the Western Cape province of South Africa, (Map courtesy of the Western Cape Department of Agriculture, South Africa) 


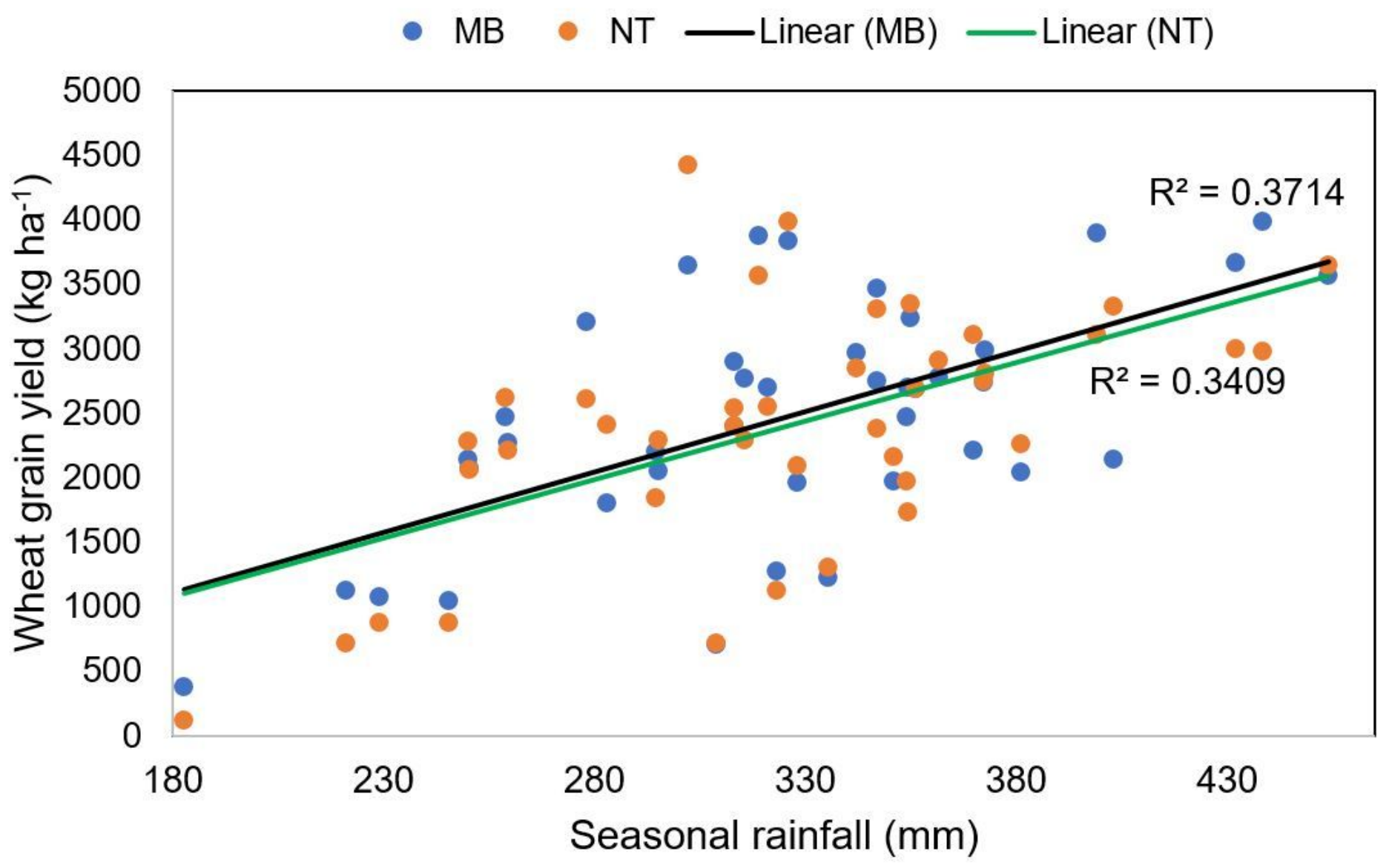

Figure 2

The relationship between seasonal rainfall (April - September) and wheat grain yield in the mouldboard (MB) and no-tillage (NT) sequences at the long-term (1976 - 2020) trial site at Langgewens Research Farm, in the Swartland region, South Africa 


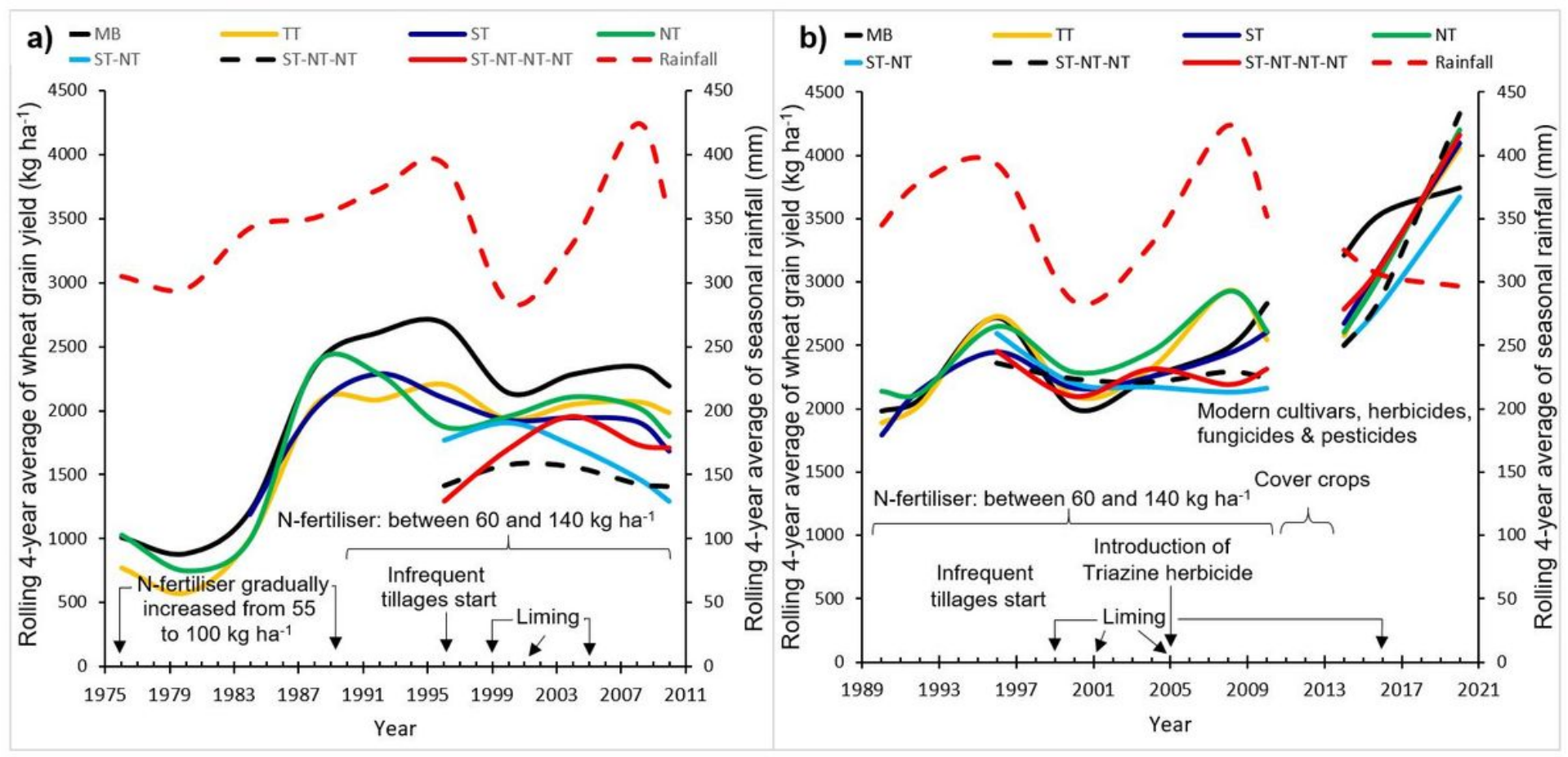

Figure 3

Rolling 4-year averages of the long-term wheat grain yield and seasonal rainfall (April - September) in the (a) monoculture system from 1976 to 2010 and (b) crop rotation (WCWL) system from 1990 to 2020 at Langgewens Research Farm in South Africa. From 1990 to 2010, N-fertiliser ranged between 60 and 140 kg ha-1 in the wheat crop, however, 65 kg ha-1 was applied from 2014 onwards 
(a) (2014)

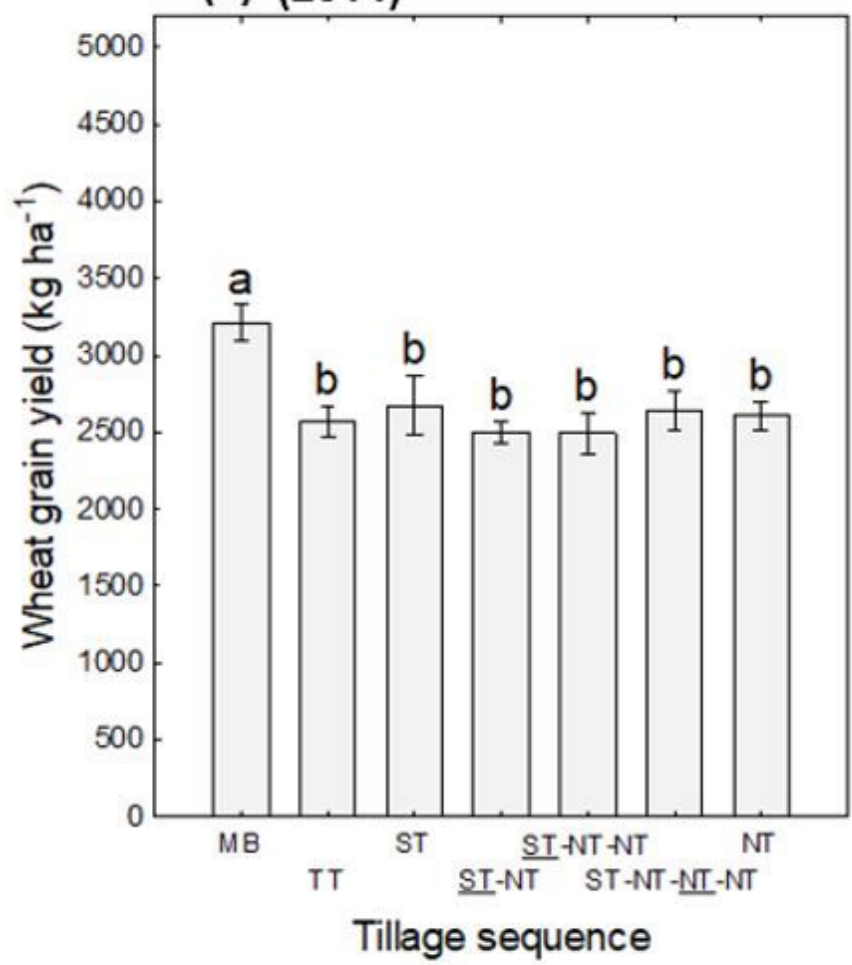

(2016) (b)

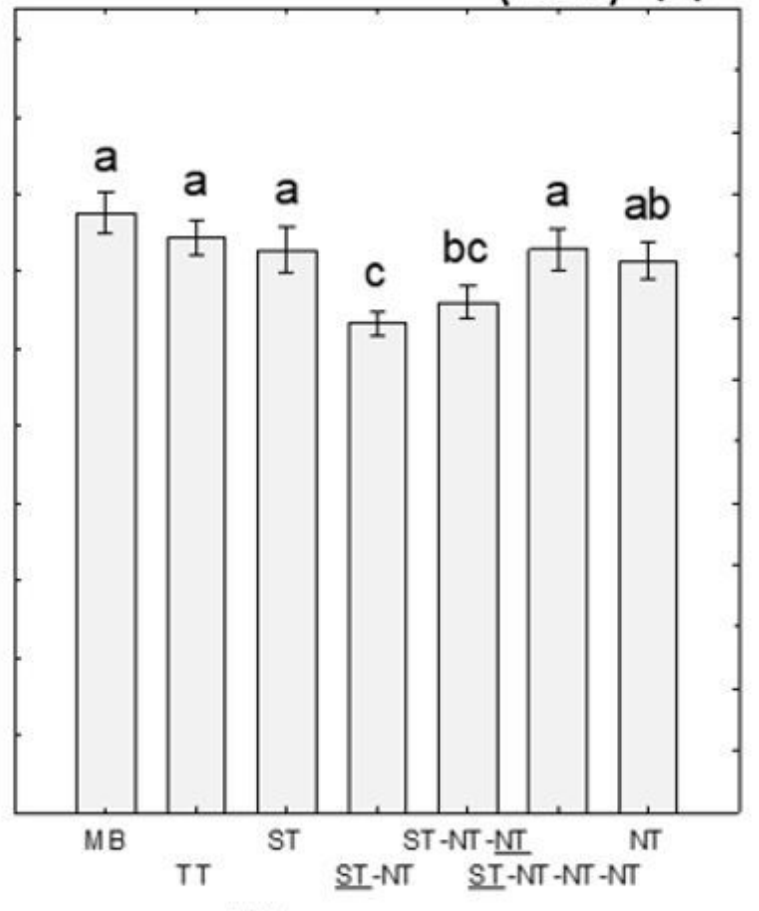

Tillage sequence

(c) (2018)
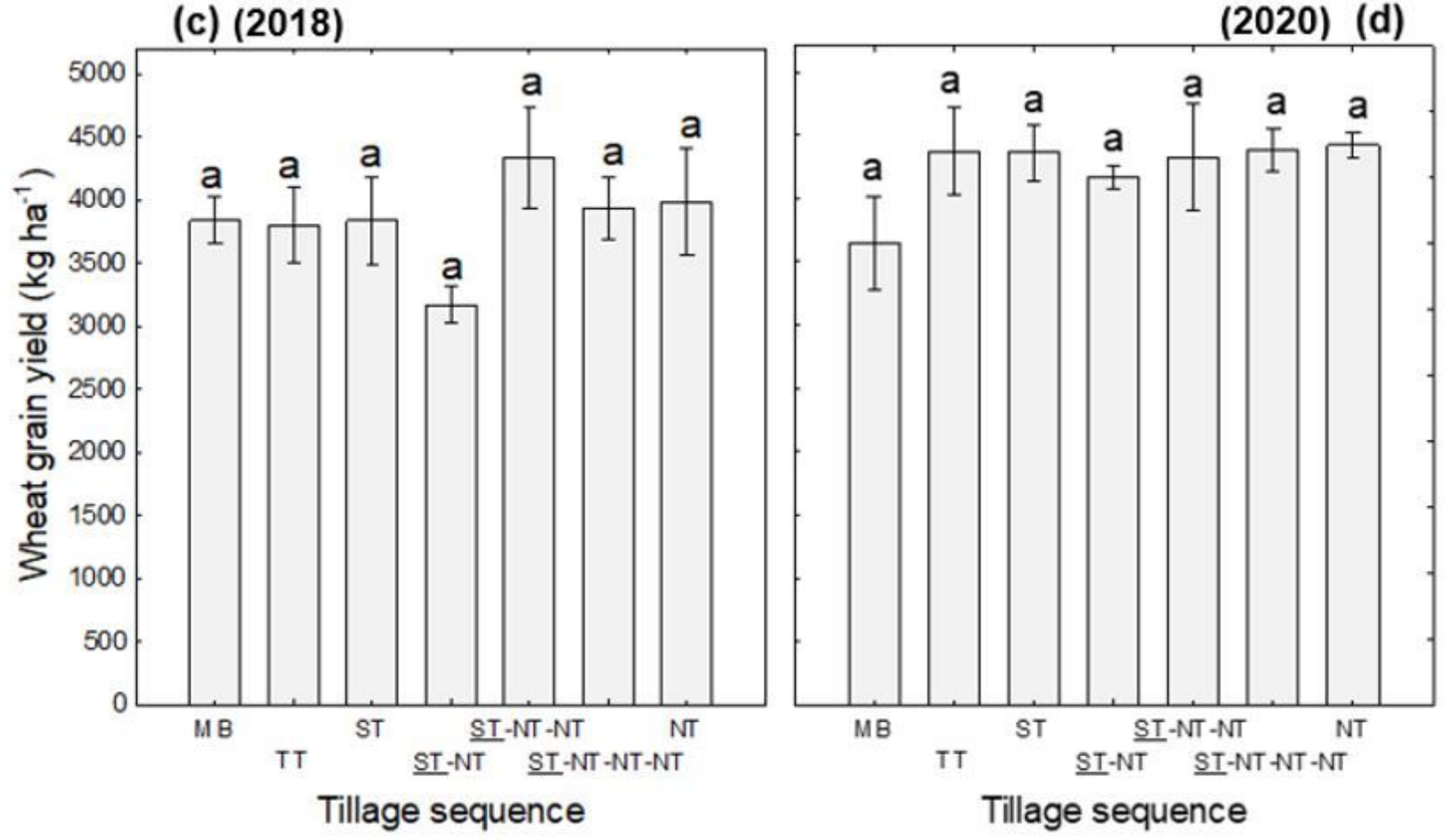

Figure 4

The wheat grain yield in (a) 2014 (b) 2016 (c) 2018 and (d) 2020, as influenced by the tillage sequences at Langgewens Research Farm. Error bars denote the standard error of the mean. MB = Mouldboard at $200 \mathrm{~mm}$ depth; TT = Tine-tillage at $150 \mathrm{~mm}$ depth; ST = Shallow tine-tillage at $75 \mathrm{~mm}$ depth; NT = Notillage. The underlined treatment in the tillage sequence indicates the tillage treatment conducted during the specific year. The different letters on top of the bars denote a significant difference $(P<0.05)$ 